\title{
The protective effect of caffeic acid against inflammation injury of primary bovine mammary epithelial cells induced by lipopolysaccharide
}

\author{
Mingjiang Liu, ${ }^{\star}$ Shixiu Song, ${ }^{*}$ Huanrong Li, $†$ Xiaoyu Jiang, ${ }^{*}$ Peng Yin, ${ }^{*}$ Changrong Wan, ${ }^{*}$ Xiaoxi Liu, ${ }^{*}$ \\ Fenghua Liu, $\dagger^{1}$ and Jianqin $X u^{* 1}$ \\ ${ }^{*}$ College of Veterinary Medicine, China Agricultural University (CAU), Beijing 100193, P. R. China \\ †College of Animal Science and Technology, Beijing University of Agriculture (BUA), Beijing 102206, P. R. China
}

\begin{abstract}
Caffeic acid possesses multiple biological effects, such as antibacterial, antioxidant, antiinflammatory, and anticancer growth; however, what effects it has on bovine mastitis have not been investigated. The aim of this study was to verify the antiinflammatory properties of caffeic acid on the inflammatory response of primary bovine mammary epithelial cells (bMEC) induced by lipopolysaccharide (LPS), and to clarify the possible underlying mechanism. Bovine mammary epithelial cells were treated with various concentrations $(10,50$, 100 , and $200 \mu \mathrm{g} / \mathrm{mL}$ ) of LPS for $3,6,12$, and $18 \mathrm{~h}$; the results showed that LPS significantly inhibited cell viability in a time- and dose-dependent manner. When cells were treated with LPS $(50 \mu \mathrm{g} / \mathrm{mL})$ for $12 \mathrm{~h}$, the cell membrane permeability significantly increased, which promoted cell apoptosis. Various concentrations $(10,25$, and $50 \mu \mathrm{g} / \mathrm{mL})$ of caffeic acid could weaken the inflammation injury of bMEC induced by LPS without cytotoxicity. Proinflammatory cytokines (IL-8, IL-1 $\beta$, IL-6, and tumor necrosis factor $\alpha$ ) from bMEC were decreased. Nuclear transcription factor $\kappa B$ activity was weakened via blocking $\kappa \mathrm{B}$ inhibitor $\alpha$ degradation and p65 phosphorylation. All these showed that the protective effect of caffeic acid on LPS-induced inflammation injury in bMEC was at least partly achieved by the decreased production of proinflammatory cytokines mediated by the effect of reducing the $\kappa \mathrm{B}$ inhibitor $\alpha$ degradation and p65 phosphorylation in the nuclear transcription factor $\kappa \mathrm{B}$ pathway. The use of caffeic acid would be beneficial in dairy cows during Escherichia coli mastitis as a safe and natural antiinflammatory drug.
\end{abstract}

Key words: bovine mammary epithelial cell, lipopolysaccharide, inflammation, caffeic acid

\footnotetext{
Received October 14, 2013.

Accepted January 21, 2014.

${ }^{1}$ Corresponding authors:
} liufenghua1209@126.com xujianqincau@126.com and

\section{INTRODUCTION}

Bovine mastitis, which causes serious economic losses, is one of the most common cow diseases throughout the world. Bacterial infections of the bovine mammary gland can result in a spectrum of clinical outcomes, ranging from acute and life threatening to chronic and subclinical, which affect mammary tissue integrity and reduce the production performance of cows (Seegers et al., 2003). Therefore, it is of prime importance to determine how to detect and eradicate bacteria earlier and control the inflammation (Menzies et al., 1995; Porcherie et al., 2012; Quesnell et al., 2012). Currently, antibiotics are still an effective treatment of bovine mastitis, but are limited because of the growing problem of drug resistance and food safety concerns over their use in recent years (Boehmer, 2011; Kerro Dego et al., 2012). Thus, safe and effective treatments of bovine mastitis continue to garner attention in veterinary research.

Coliform mastitis is often characterized by severe inflammation and impaired milk production, which can even lead to death of the animal. Escherichia coli is one of the major mastitis pathogens responsible for clinical mastitis in cows (Burvenich et al., 2003; Bradley et al., 2007; Botrel et al., 2010). Lipopolysaccharide, a major integral structural component of the outer membrane of $E$. coli and one of the best-studied microbial products, is a potent initiator of inflammation and endotoxin shock. Toll-like receptor 4 (TLR4) is indispensable for LPS signaling (Shimazu et al., 1999; Miyake, 2004). The TLR4-LPS interaction leads to the rapid and coordinated activation of various intracellular signaling pathways, including the mitogen-activated protein kinase (MAPK) cascades, translocation of nuclear factor $\kappa \mathrm{B}(\mathbf{N F}-\kappa \mathbf{B})$, and so on (Risco et al., 2012; Hines et al., 2013). Nuclear factor $\kappa B$ regulates the expression of cytokines, chemokines, antiapoptotic, and cell growth factors, which are essential mediators of immune and inflammatory responses. Thus, inhibition of NF- $\mathrm{NB}$ activation has attracted attention as a therapeutic approach for intervention in immune and inflammatory events (Li and Verma, 2002; Calzado et al., 2007). 
In the cow udder, the expression of TLR2 and TLR4 has frequently been demonstrated (Petzl et al., 2008; Bougarn et al., 2010). The mammary immune response to LPS has been studied in vitro (Wellnitz and Kerr, 2004; Strandberg et al., 2005; Günther et al., 2012) and in vivo (Schmitz et al., 2004; Wellnitz et al., 2010; Morimoto et al., 2012), and the initial response is similar to that for whole bacteria (Hoeben et al., 2000; Wellnitz and Bruckmaier, 2012). Those studies clearly demonstrate that mammary epithelial cells have a strong innate immune defense capability and capacity to attract circulating immune effector cells, such as neutrophils (Strandberg et al., 2005; Ibeagha-Awemu et al., 2008), but fewer studies have focused on the excessive inflammatory response of epithelial cells affecting themselves, or reduced inflammatory injury of breast tissue by weakening the immune response.

Caffeic acid, a natural phenolic compound, is abundant in medicinal plants. Caffeic acid and its synthetic derivatives possess multiple biological effects such as antibacterial, antioxidant, antiinflammatory, and anticancer growth (Shin et al., 2004; Jung et al., 2007; Búfalo et al., 2013). Caffeic acid could act on multiple signaling pathways associated with inflammation in various cell lines. It could inhibit LPS-induced inflammation response of mouse leukemic monocyte macrophage (Raw 264.7) cells through the inhibition of NF- $\kappa \mathrm{B}$, p38 MAPK, and c-Jun $\mathrm{NH}_{2}$-terminal kinase 1/2 activation (Puangpraphant et al., 2011; Búfalo et al., 2013). However, the effect of caffeic acid on mastitis has not been investigated. The aim of this study was to investigate the protective effect of caffeic acid against LPS-induced inflammation injury of bovine mammary epithelial cells (bMEC) and to clarify the possible mechanisms.

\section{MATERIALS AND METHODS}

\section{bMEC Isolation, Cell Culture, and Treatment}

Bovine mammary epithelial cells were isolated from 5 lactating cows as previously described and cryopreserved in liquid nitrogen (Lahouassa et al., 2007; Porcherie et al., 2012). Cells were incubated at $37^{\circ} \mathrm{C}$ in $5 \% \mathrm{CO}_{2}$. Cells cultured in medium consisting of Dulbecco's modified Eagle's medium/Ham's F-12 nutrient mixture (DMEM/F12) supplemented with $10 \%$ fetal bovine serum (Gibco, Grand island, NY), $100 \mathrm{U} / \mathrm{mL}$ of antibiotic (penicillin and streptomycin; Sigma-Aldrich, St. Louis, MO), $5 \mu \mathrm{g} / \mathrm{mL}$ of insulin, $1 \mu \mathrm{g} / \mathrm{mL}$ of hydrocortisone, $5 \mu \mathrm{g} / \mathrm{mL}$ of transferrin, and $1 \mu \mathrm{g} / \mathrm{mL}$ of progesterone (Sigma-Aldrich) were used at passage 3 or 4 for further research.
Caffeic acid (>98\% purity; National Institutes for Food and Drug Control, Beijing, China) and LPS ( $E$. coli serotype O55:B5, Sigma-Aldrich) were diluted in DMEM/F12 medium (1 mg/mL). All cells were washed with serum-free medium and serum starved for $2 \mathrm{~h}$ before incubation with caffeic acid or LPS.

\section{Cell Viability Assay and Flow Cytometric Analysis}

To measure cell viability, equivalent numbers of bMEC were plated on 96-well multiplies and cultured in DMEM/F12 medium containing 5\% fetal bovine serum at a density of $1.2 \times 10^{5}$ cells $/ \mathrm{mL}$. After cells were grown to $90 \%$ confluence, all cells were washed twice with PBS and serum starved for $2 \mathrm{~h}$ before incubation with caffeic acid or LPS for different times, and then 10 $\mu \mathrm{L}$ of 3-(4,5-dimethylthiazol-2-yl)-2,5-diphenyltetrazolium bromide (MTT; $5 \mathrm{mg} / \mathrm{mL}$; Amresco LLC, Solon, $\mathrm{OH})$ was added to each well and incubated at $37^{\circ} \mathrm{C}$ for $4 \mathrm{~h}$, and well media was aspirated and the formazan product dissolved using dimethyl sulfoxide (Amresco LLC). The remaining formazan product was analyzed using a microplate reader (Bio-Rad Laboratories Inc., Foster City, CA) at a fixed absorption wavelength of $490 \mathrm{~nm}$ and reference wavelength of $630 \mathrm{~nm}$.

To analyze apoptosis, cells were treated with LPS or caffeic acid according to the experimental requirements. Following each specific treatment, all cells were trypsinized (Gibco), washed twice with PBS, and then stained with annexin $\mathrm{V} /$ propidium iodide (Invitrogen Inc., Carlsbad, CA), and flow cytometric analysis was performed according to the manufacturer's instructions (Beckman Coulter Inc., Fullerton, CA).

\section{RNA Extraction and Gene mRNA Expression Analysis}

Total RNA was isolated from bMEC using a phenol and guanidine isothiocyanate-based TRIzol reagent (Invitrogen Inc.) according to the manufacturer's instructions. The RNA quality assessment and reverse transcription (RT) were performed as previously described (Yu et al., 2010a). Reverse transcription-generated cDNA encoding $\beta$-actin, IL- $1 \beta$, tumor necrosis factor $\alpha$ ( TNF- $\alpha)$, IL-6, and IL- 8 were amplified by real-time PCR using selective primers listed in Table 1. Quantitative PCR analysis was carried out as previously described ( $\mathrm{Yu}$ et al., 2010b). The PCR reaction system $(25 \mu \mathrm{L}$ in total) contained $12.5 \mu \mathrm{L}$ of SYBR Green PCR mix (Stratagene, La Jolla, CA), $0.375 \mu \mathrm{L}$ of reference dye, $1 \mu \mathrm{L}$ of each primer (both $10 \mu \mathrm{mol} / \mathrm{L}$ ), $1 \mu \mathrm{L}$ of cDNA template, and $9.125 \mu \mathrm{L}$ of diethylpyrocarbonate-treated water. 
Table 1. Gene-specific oligonucleotide primers used for reverse-transcription PCR

\begin{tabular}{|c|c|c|c|}
\hline Item & Accession number ${ }^{1}$ & Primer sequence $\left(5^{\prime} \rightarrow 3^{\prime}\right)^{2}$ & $\begin{array}{l}\text { Product size } \\
\text { (bp) }\end{array}$ \\
\hline$\beta$-actin & NM_173979.3 & $\begin{array}{l}\text { F: CCTGCGGCATTCACGAAACTAC } \\
\text { R: ACTCCTGCTTGCTGATCCACATC }\end{array}$ & 273 \\
\hline IL-1 $\beta$ & NM_174093.1 & $\begin{array}{l}\text { F: GGCAACCGTACCTGAACCCA } \\
\text { R: CCACGATGACCGACACCACC }\end{array}$ & 206 \\
\hline
\end{tabular}

${ }^{1}$ Primers were designed from the published sequences in the GenBank database under the indicated accession numbers.

${ }^{2} \mathrm{~F}=$ forward primer; $\mathrm{R}=$ reverse primer.

${ }^{3}$ Tumor necrosis factor $\alpha$.

\section{Western Blot Analysis}

Proteins from bMEC were extracted using a total protein extraction kit (BioChain Institute Inc., Hayward, CA) and quantified using a BCA protein assay kit (Pierce Biotechnology Inc., Rockford, IL). Proteins (10-20 $\mu \mathrm{g} /$ sample) were separated by SDS-PAGE (Invitrogen Inc.), transferred to nitrocellulose membranes (Pierce Biotechnology Inc.), and then hybridized with the specific antibodies. The following antibodies were used: $\kappa \mathrm{B}$ inhibitor $\alpha(\mathbf{I} \boldsymbol{\kappa} \mathbf{B} \boldsymbol{\alpha})$, p65, phospho-p65, $\beta$-actin (4814s, 4764s, 3039s, 4970s; Cell Signaling Technology, Danvers, MA). Blots were normalized by using $\beta$-actin to correct for differences in loading of the proteins. Proteins were detected using an Odyssey Infrared Imaging System (LI-COR Biosciences, Lincoln, NE). Densitometric values of immunoblot signals were obtained from 3 separate experiments using Image J software (National Institutes of Health, Bethesda, MD).

\section{Statistical Analysis}

Unless indicated otherwise, all data were obtained from at least 3 independent experiments performed in triplicate and the results were presented as mean and standard error of the mean. Statistical analysis was performed using one-way ANOVA, followed by Duncan's test for multiple comparisons. Statistical significance was assigned to $P<0.05$.

\section{RESULTS}

\section{The Inflammation Injury of bMEC Induced by LPS}

To determine the effect of inflammatory injury on bMEC induced by LPS, cell viability was tested after cells were treated with various concentrations $(10,50$, 100 , and $200 \mu \mathrm{g} / \mathrm{mL}$ ) of LPS for 3, 6, 12, and $18 \mathrm{~h}$. As shown in Figure 1A, cell viability was not changed after treated with various concentrations of LPS for 3 h. After being stimulated with 100 or $200 \mu \mathrm{g} / \mathrm{mL}$ of LPS for $6 \mathrm{~h}$, cell vitality was significantly $(P<0.05, P$ $<0.001)$ inhibited. An obvious $(P<0.05)$ decrease in cell viability occurred after treatment with $50 \mu \mathrm{g} / \mathrm{mL}$ of LPS for $12 \mathrm{~h}$, and the effect of cell viability inhibition induced by 100 or $200 \mu \mathrm{g} / \mathrm{mL}$ of LPS was more serious $(P<0.001)$. Cell vitality was significantly $(P<0.01)$ decreased after treated with all concentrations of LPS for $18 \mathrm{~h}$.

Cell apoptosis was significantly increased after cells were stimulated with $50 \mu \mathrm{g} / \mathrm{mL}$ of LPS for $12 \mathrm{~h}$ (Figure 1B), which was consistent with the above research in this study. These conditions were chosen as the model conditions of inflammation injury of bMEC induced by LPS for further research.

\section{The Cytotoxicity of Caffeic Acid on bMEC}

To investigate the cytotoxicity of caffeic acid on bMEC, cell viability was tested after being treated with various concentrations $(10,25,50,100$, and $200 \mu \mathrm{g} /$ $\mathrm{mL}$ ) of caffeic acid for 24 and $48 \mathrm{~h}$. Various concentrations of caffeic acid had a marked role in promoting cell proliferation without cytotoxicity, and this effect was in a time- and dose-dependent manner in the range of 10 to $100 \mu \mathrm{g} / \mathrm{mL}$ (Figure 2). According to the results, concentrations of 10,25 , and $50 \mu \mathrm{g} / \mathrm{mL}$ of caffeic acid were chosen to study the protective effects of caffeic acid against inflammation injury of primary bMEC induced by LPS.

\section{Caffeic Acid Effectively Protects bMEC from Inflammatory Injury Induced by LPS}

To determine the protective effect of caffeic acid in inflammatory injury of bMEC induced by LPS, cell viability and cell apoptosis were detected after treatment 

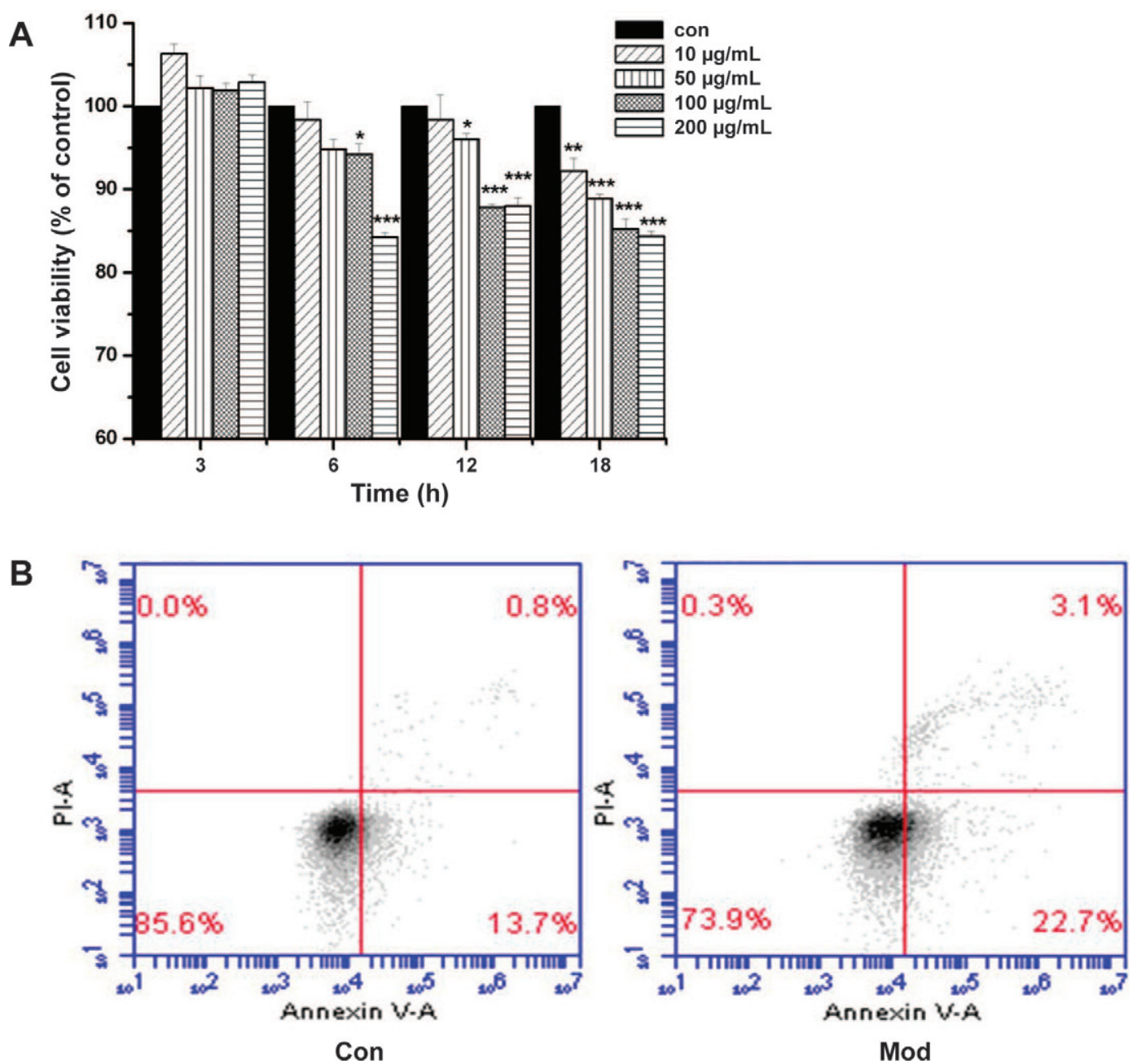

Figure 1. The inflammation injury of bovine mammary epithelial cells (bMEC) induced by LPS. (A) Cell viability was measured by 3-(4,5-dimethylthiazol-2-yl)-2,5-diphenyltetrazolium bromide (MTT) following treatment with various concentrations (10, 50, 100, and 200 $\mu \mathrm{g} /$ $\mathrm{mL}$ ) of LPS for $3,6,12$, and $18 \mathrm{~h}$. Cell viability could be reduced by LPS in a time- and dose-dependent manner. The data are means \pm SEM $(\mathrm{n}=6) .{ }^{*} P<0.05$ vs. control group; ${ }^{* *} P<0.01$ vs. control group; ${ }^{* * *} P<0.001$ vs. control group. (B) After bMEC were treated with $50 \mu \mathrm{g} /$ $\mathrm{mL}$ of LPS for $12 \mathrm{~h}$, the percentage of cells undergoing apoptosis was determined by flow cytometry following annexin V/propidium iodide (PI) staining. Cells that were positive for annexin V but not PI, which are present in the lower right quadrant, were early-apoptotic cells. Cells that were both annexin V and PI positive, which are present in the upper right quadrant, were late-apoptotic cells. Con = control cells without any processing; Mod $=$ cells treated with $50 \mu \mathrm{g} / \mathrm{mL}$ of LPS. Color version available in the online PDF.

with caffeic acid or LPS. A decrease in cell viability induced by LPS was significantly $(P<0.05)$ inhibited by 25 and $50 \mu \mathrm{g} / \mathrm{mL}$ of caffeic acid (Figure $3 \mathrm{~A}$ ) and the apoptosis of bMEC induced by LPS, especially early apoptosis, was significantly reduced by caffeic acid in a dose-dependent manner (Figures $3 \mathrm{~B}$ and $\mathrm{C}$ ).

\section{Effects of Caffeic Acid on LPS-Induced Proinflammatory Cytokines Production}

In this study, the inflammation injury of bMEC induced by LPS could be weakened by caffeic acid, so the

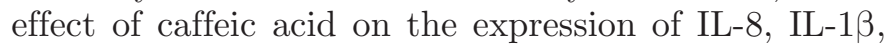
IL-6, and TNF- $\alpha$ in bMEC induced by LPS was examined by RT-PCR.
The expression of IL-8, IL-1 $\beta$, IL- 6 , and TNF- $\alpha$ induced by LPS was significantly upregulated at indicated time points (Figure 4). This effect was markedly inhibited by caffeic acid in a dose-dependent manner (Figure 4). Thus, the antiinflammatory effect of caffeic acid was confirmed in the inflammation response of bMEC induced by LPS.

\section{Caffeic Acid Blocking IkBa Degradation and p65 Phosphorylation}

Nuclear factor $\kappa \mathrm{B}$ is the most classic inflammatory signaling pathway. With the objective of determining the effect of caffeic acid on the NF- $\kappa \mathrm{B}$ pathway, we investigated the critical proteins of the signal pathway 


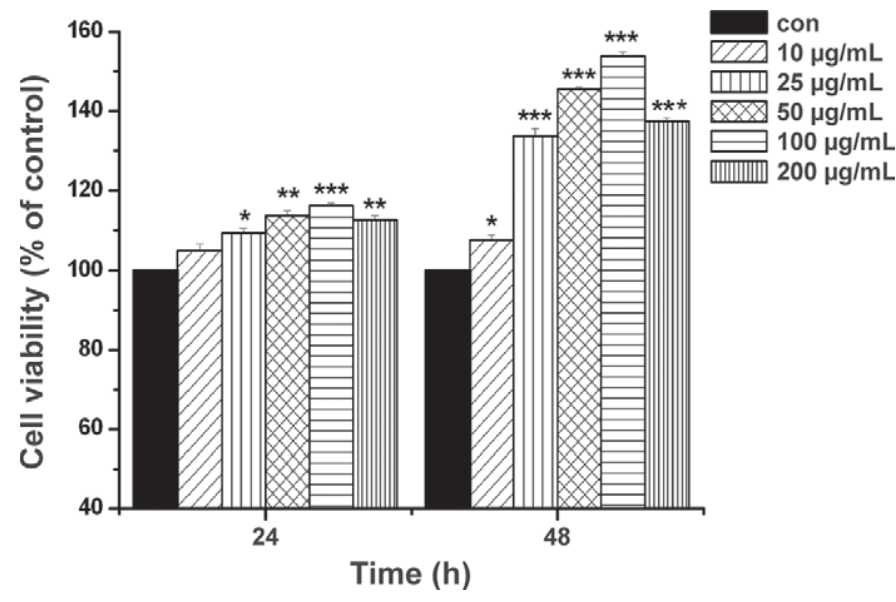

Figure 2. The cytotoxicity of caffeic acid on bovine mammary epithelial cells (bMEC). Cell viability was measured by 3-(4,5-dimethylthiazol-2-yl)-2,5-diphenyltetrazolium bromide (MTT) following treatment with various concentrations $(10,25,50,100$, and $200 \mu \mathrm{g} /$ $\mathrm{mL}$ ) of caffeic acid for 24 and $48 \mathrm{~h}$. Cell proliferation was significantly promoted by caffeic acid, and the effect was time and dose dependent. The data are means \pm SEM $(\mathrm{n}=6) .{ }^{*} P<0.05$ vs. control group; ${ }^{* *} P<0.01$ vs. control group; ${ }^{* * *} P<0.001$ vs. control group. con $=$ control cells without any processing.

by Western blot. Almost a complete $(P<0.001)$ degradation of $\mathrm{I} \kappa \mathrm{B} \alpha$ and significant $(P<0.001)$ increase in p-p65 are shown in Figure 5A and B after cells were treated with LPS for $0.5 \mathrm{~h}$, indicating an increase in the NF- $\kappa \mathrm{B}$ activity. The degradation of $\mathrm{I} \kappa \mathrm{B} \alpha$ and phosphorylation of p65 induced by LPS were partially inhibited by caffeic acid in a dose-dependent manner (Figure 5A and B), which indicated a weakening activity of NF- $\kappa \mathrm{B}$. After $1 \mathrm{~h}$, the I $\kappa \mathrm{B} \alpha$ degradation and p65 phosphorylation were decreased in all groups (Figure $5 \mathrm{~A}$ and $\mathrm{B}$ ). Data showed that the NF- $\kappa \mathrm{B}$ activity in bMEC induced by LPS was significantly inhibited by caffeic acid.

\section{DISCUSSION}

In this study, we determined that LPS induced inflammation injury of bMEC (Figures 1A and B) and these effects could be weakened by caffeic acid without cytotoxicity (Figures 2 and 3). Then, the possible antiinflammatory mechanisms of caffeic acid were researched.

A rapid inflammatory response stimulated by LPS has been confirmed in mammary epithelium, which was characterized by releasing a large number of proinflammatory cytokines (IL-8, IL-1 $\beta$, IL-6, and TNF- $\alpha$ ) (Strandberg et al., 2005; Günther et al., 2012). This is beneficial for the attraction of circulating immune effector cells, such as neutrophils, to fight infection (Porcherie et al., 2012), but excessive inflammation response will injure tissue and cells. Therefore, the expression of proinflammatory cytokines needs to be tightly regulated during an inflammatory response (Shuster et al., 1997; Scheibel et al., 2010). Our study found that a significant inhibition of cell viability could be induced by LPS over time and dose (Figure 1A); in addition, cell microstructure was damaged (data not shown), which promoted cell apoptosis (Figure 1B). Therefore, we found that the effect of LPS on bMEC was not just the inhibition of cell proliferation, which is different from the research results obtained before (Calvinho et al., 2001; Wellnitz and Kerr, 2004). We found that LPS-caused inflammation could injure bMEC and this effect could reduce the production performance of cows.

Caffeic acid has been reported to exert diverse biological activities, such as antiinflammatory effects (Lee et al., 2010; Búfalo et al., 2013). Here, we studied the protective effect of caffeic acid against LPS-induced inflammation injury of bMEC. Caffeic acid effectively decreased inhibition of cell viability (Figure 3A) and cell apoptosis induced by LPS (Figure 3B). The potential effect of caffeic acid on the expression of the proinflammatory cytokines (IL-8, IL-1 $\beta$, IL-6, and TNF- $\alpha$ ) were analyzed by RT-PCR. As expected, the expression of IL-8, IL-1 $\beta$, IL-6, and TNF- $\alpha$ was upregulated at all time points after LPS stimulation (Figure 4). Caffeic acid could effectively inhibit the expression of IL-8, IL$1 \beta$, IL-6, and TNF- $\alpha$ (Figure 4) in a dose-dependent manner, which protected bMEC from LPS-induced inflammation injury.

Nuclear factor $\kappa \mathrm{B}$ is crucial for numerous cellular processes such as inflammation, cell survival, development, immune processes, and apoptosis ( $\mathrm{Li}$ and Verma, 2002; Lee et al., 2010; Scheibel et al., 2010). Activators of the NF-kB pathway, such as LPS, strongly enhance the phosphorylation of the I $\kappa \mathrm{B}$ proteins ( $\mathrm{I} \kappa \mathrm{B} \alpha$ is the principal inhibitory protein of $\mathrm{NF}-\kappa \mathrm{B}$ ), leading to their rapid proteasomal degradation (Karin and BenNeriah, 2000; Ghosh and Hayden, 2008). Nuclear factor $\kappa \mathrm{B}$ dimers (the primary $\mathrm{NF}-\kappa \mathrm{B}$ isoform induced by proinflammatory stimuli is the P50:P65 dimer) are released and phosphorylated after the degradation of $\mathrm{I} \kappa \mathrm{B}$, which are able to enter the nucleus and bind specifically to defined DNA sequences to promote target gene expression (Tran et al., 1997; Yamamoto et al., 2004; Hoffmann and Baltimore, 2006). Thus, inhibition of NF- $\kappa \mathrm{B}$ activation has attracted attention as a therapeutic approach for intervention in immune and inflammatory events (Lee et al., 2010).

The data showed that the degradation of $\mathrm{I} \kappa \mathrm{B} \alpha$ and the phosphorylation of p65 were significantly increased after stimulation with LPS for $0.5 \mathrm{~h}$ (Figure $5 \mathrm{~A}$ and B), which indicated an obviously enhanced activation of $\mathrm{NF}-\kappa \mathrm{B}$ and resulted in a high expression of proinflam- 


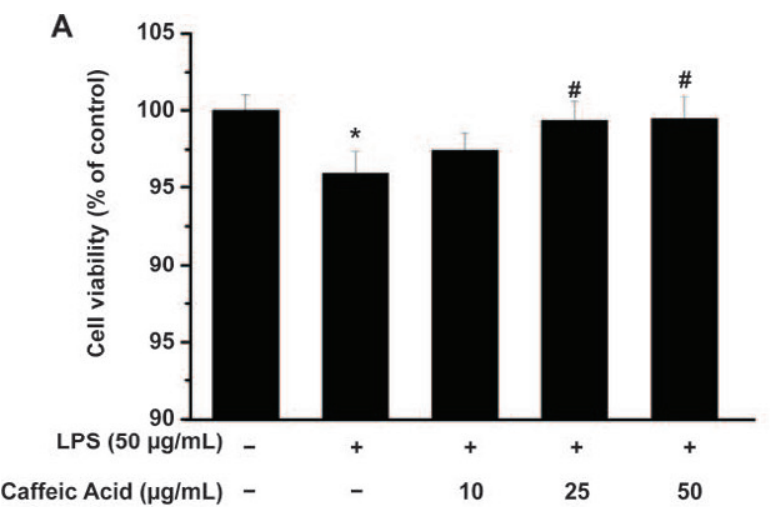

B

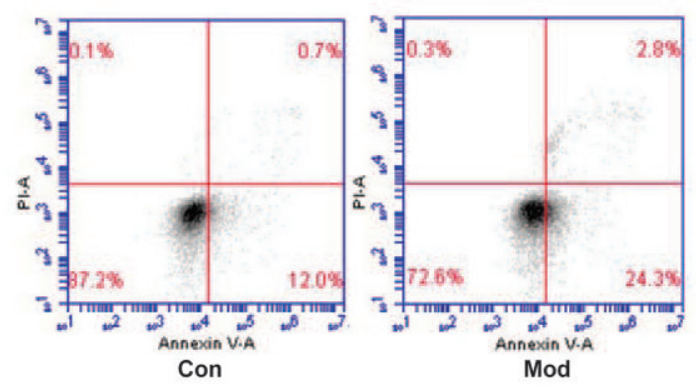

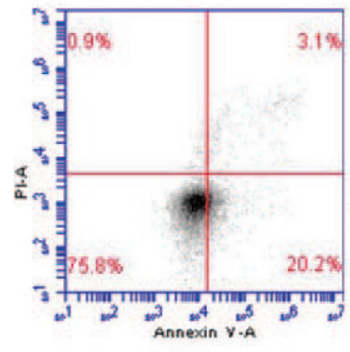

Low

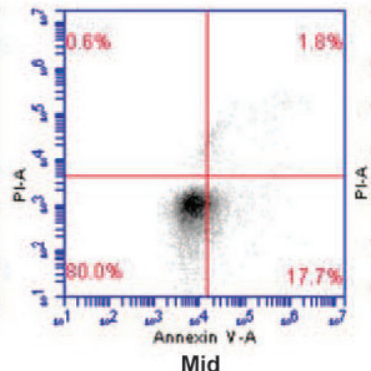

Mid

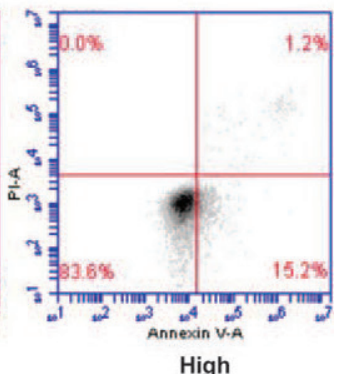

High

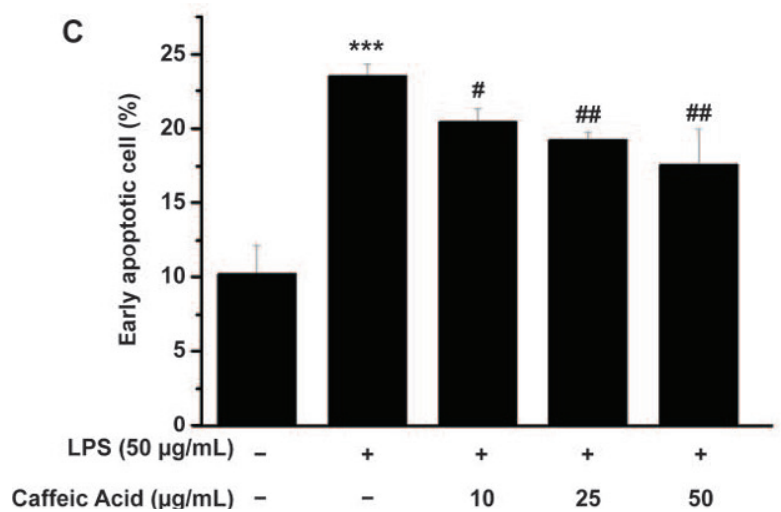

Figure 3. Caffeic acid effectively protected bovine mammary epithelial cells (bMEC) from injury induced by LPS. Cells were treated with indicated concentrations $(10,25$, and $50 \mu \mathrm{g} / \mathrm{mL}$ ) of caffeic acid or serum-free medium for $3 \mathrm{~h}$ before stimulation with $50 \mu \mathrm{g} / \mathrm{mL}$ of LPS for $12 \mathrm{~h}$. (A) Cell viability was measured by 3-(4,5-dimethylthiazol-2-yl)-2,5-diphenyltetrazolium bromide $(\mathrm{MTT})$. The data are means $\pm \mathrm{SEM}(\mathrm{n}=6)$. ${ }^{*} P<0.05$ vs. control group; ${ }^{\#} P<0.05$ vs. group treated with LPS only. (B) After cells were treated with caffeic acid or LPS, the percentage of cells undergoing apoptosis was determined by flow cytometry following annexin V/propidium iodide (PI) staining. Cells that were positive for annexin V but not PI, which are present in the lower right quadrant, were early-apoptotic cells. Cells that were both annexin V and PI positive, which are present in the upper right quadrant, were late-apoptotic cells. Con $=$ control cells without any processing; Mod $=$ cells treated with LPS $(50 \mu \mathrm{g} / \mathrm{mL})$ only; Low $=$ caffeic acid $(10 \mu \mathrm{g} / \mathrm{mL})+$ LPS $(50 \mu \mathrm{g} / \mathrm{mL}) ;$ Mid $=$ caffeic acid $(25 \mu \mathrm{g} / \mathrm{mL})+\mathrm{LPS}(50 \mu \mathrm{g} / \mathrm{mL}) ; \mathrm{High}=\mathrm{caffeic}$ acid $(50 \mu \mathrm{g} / \mathrm{mL})+$ LPS $(50 \mu \mathrm{g} / \mathrm{mL})$. One out of 3 independent experiments is shown. (C) The analysis of the early apoptosis rates in the lower right quadrant of panel $\mathrm{B}$. The data are means \pm SEM $(\mathrm{n}=3)$. ${ }^{* * *} P<0.001 \mathrm{vs}$. control group; ${ }^{\#} P<0.05$ vs. group treated with LPS only;

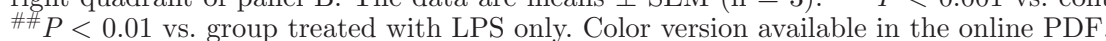



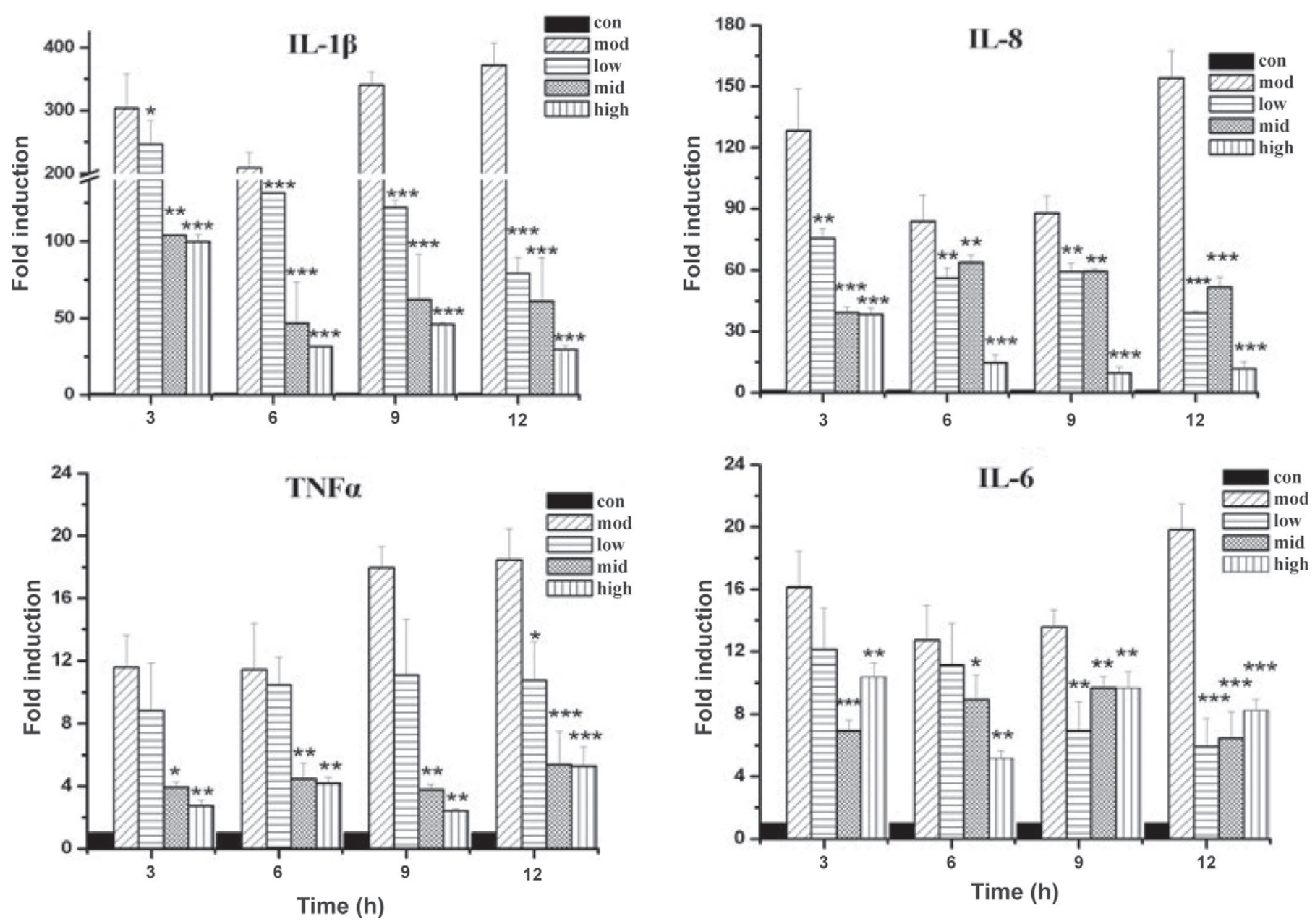

Figure 4. The effect of caffeic acid on production of proinflammatory cytokines induced by LPS in bovine mammary epithelial cells (bMEC). Cells were incubated with various concentrations of caffeic acid or serum-free medium for $3 \mathrm{~h}$ and subsequently challenged with $50 \mu \mathrm{g} / \mathrm{mL}$ of LPS for $0,3,6,9$, and $12 \mathrm{~h}$. Total RNA was prepared at the indicated time points after LPS injection. The IL-8, IL-1 $\beta$, IL-6, and tumor necrosis factor $\alpha(\mathrm{TNF}-\alpha)$ mRNA expression levels were quantified using reverse-transcription PCR analysis. con $=$ control cells without any processing; mod $=$ cells treated with LPS $(50 \mu \mathrm{g} / \mathrm{mL})$ only; low $=$ caffeic acid $(10 \mu \mathrm{g} / \mathrm{mL})+$ LPS $(50 \mu \mathrm{g} / \mathrm{mL}) ;$ mid $=$ caffeic acid $(25 \mu \mathrm{g} / \mathrm{mL})+\mathrm{LPS}(50 \mu \mathrm{g} / \mathrm{mL})$; high $=$ caffeic acid $(50 \mu \mathrm{g} / \mathrm{mL})+\operatorname{LPS}(50 \mu \mathrm{g} / \mathrm{mL})$. The data are means \pm SEM $(\mathrm{n}=3) . * P<0.05$ vs. group treated with LPS only; $* * P<0.01$ vs. group treated with LPS only; ${ }^{* * *} P<0.001$ vs. group treated with LPS only. Similar results were obtained from 2 additional experiments.

matory cytokines (Figure 4). Caffeic acid decreased the degradation of $\mathrm{I} \kappa \mathrm{B} \alpha$ and phosphorylation of p65 at $0.5 \mathrm{~h}$ in a dose-dependent manner (Figure $5 \mathrm{~A}$ and $\mathrm{B}$ ), suggesting an inhibitory effect of NF- $\kappa \mathrm{B}$ activity. Research has shown that I $\kappa \mathrm{B} \alpha$ was rapidly degraded upon stimulation, followed by immediate NF- $\kappa \mathrm{B}$-dependent resynthesis, and newly synthesized $\mathrm{I} \kappa \mathrm{B} \alpha$ entered the nucleus and removed NF- $\kappa \mathrm{B}$ complexes from the DNA to export them back to the cytoplasm, thus reducing excessive inflammation (Sun et al., 1993; Klement et al., 1996; Hoffmann et al., 2002). In the current study, the degradation of $\mathrm{I} \kappa \mathrm{B} \alpha$ and the phosphorylation of p65 were rapidly reduced after $1 \mathrm{~h}$ due to the synthesis of $\mathrm{I} \kappa \mathrm{B} \alpha$ in all groups (Figure $5 \mathrm{~A}$ and $\mathrm{B}$ ), which was consistent with previous research (Hoffmann et al.,
2002). Therefore, the inhibition of proinflammatory cytokine production was mediated by downregulating $\mathrm{NF}-\kappa \mathrm{B}$ pathways through preventing $\mathrm{I} \kappa \mathrm{B} \alpha$ degradation and p65 phosphorylation. Ultimately, the inflammatory injury of LPS-induced bMEC was significantly weakened.

Various intracellular signaling pathways are involved in the modulation of NF- $\kappa \mathrm{B}$ and inflammatory mediator expression. Nuclear factor $\kappa \mathrm{B}$ activation may be responsible, in part, for increased inflammatory mediator production (Jung et al., 2008; Wang et al., 2010). Mitogen-activated protein kinases are a group of signaling molecules that play an important role in inflammatory processes, and LPS treatment results in the phosphorylation of p38 MAPK, extracellular 
A

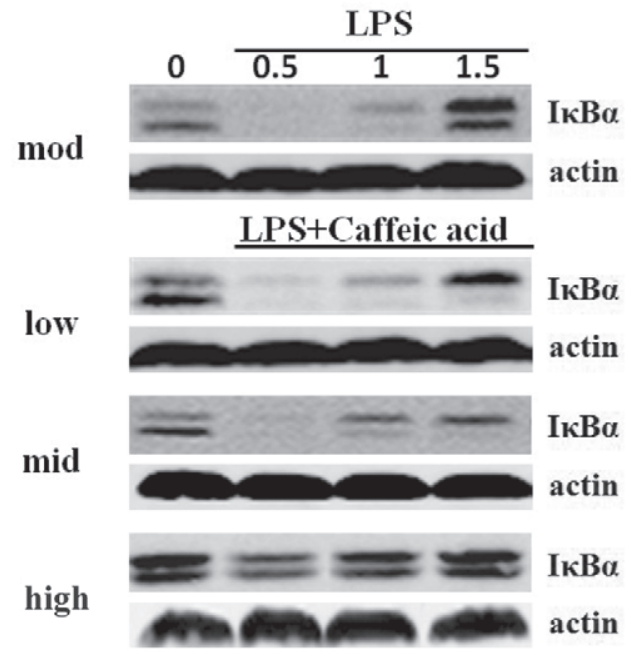

B

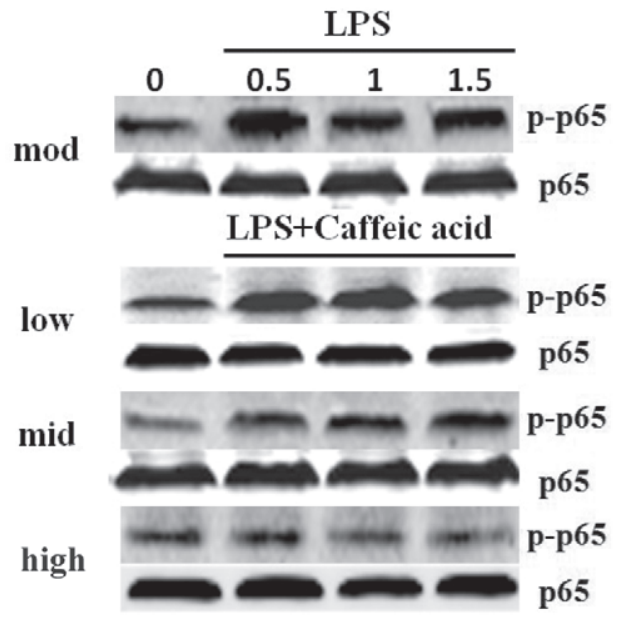

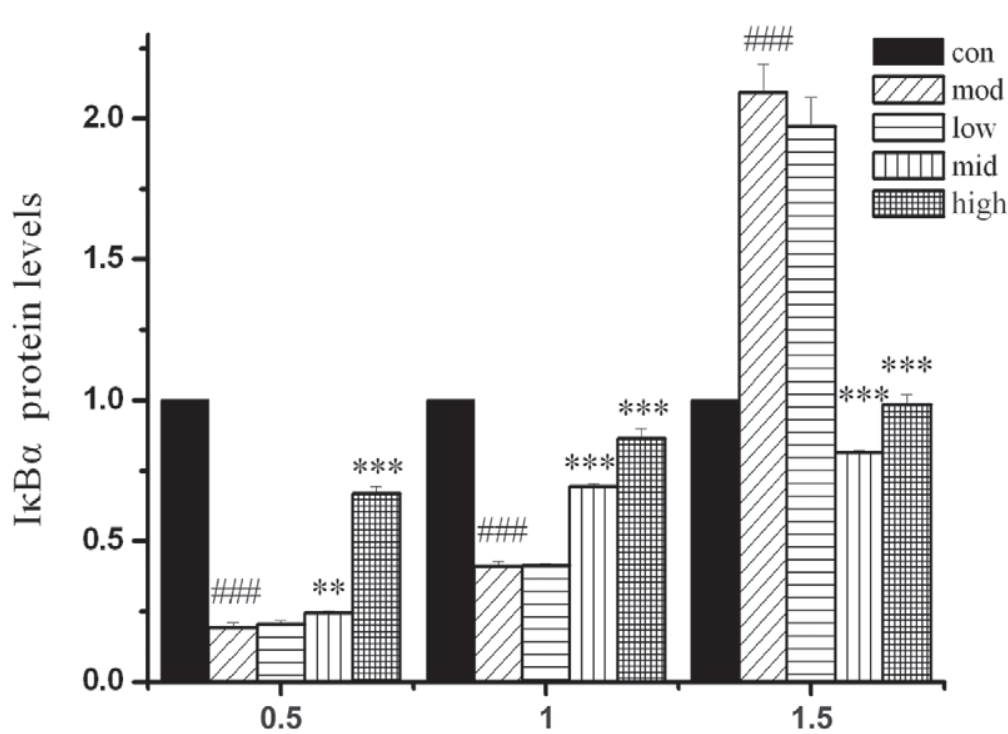
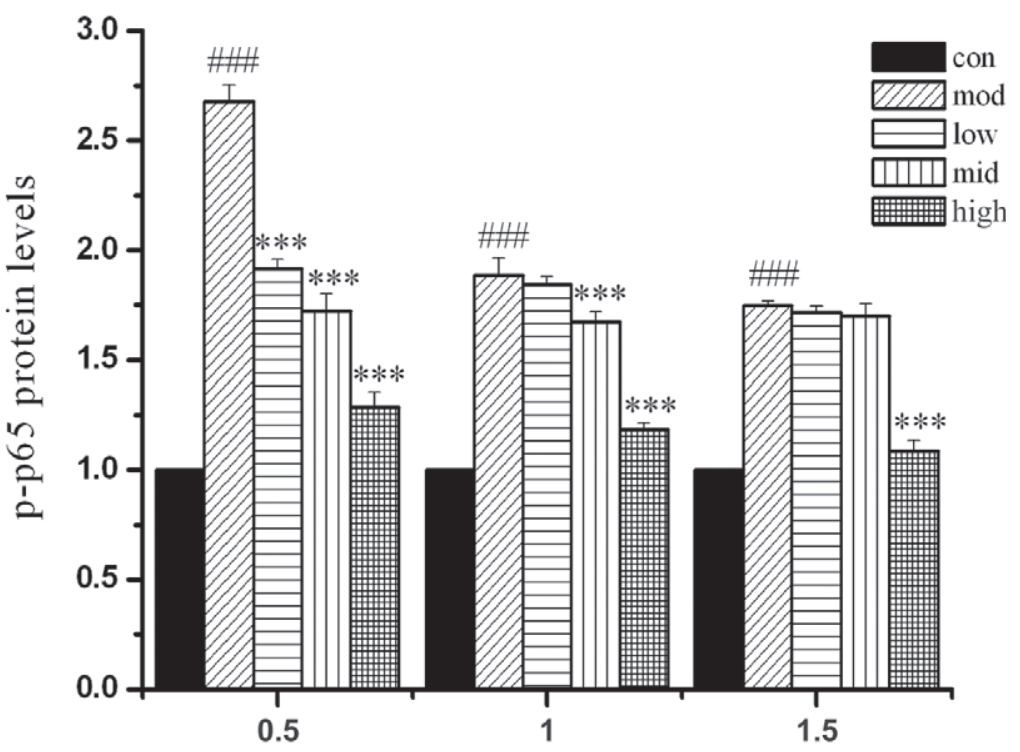

Time (h)

Figure 5. Effect of caffeic acid on LPS-induced $\kappa \mathrm{B}$ inhibitor $\alpha(\mathrm{I} \kappa \mathrm{B} \alpha)$ degradation and p65 phosphorylation in bovine mammary epithelial cells (bMEC). Cells were pretreated with various concentrations $(10,25$, and $50 \mu \mathrm{g} / \mathrm{mL})$ of caffeic acid or serum-free medium for $3 \mathrm{~h}$ and then stimulated with $50 \mu \mathrm{g} / \mathrm{mL}$ of LPS for $1.5,1$, and $0.5 \mathrm{~h}$ after washing twice with PBS. Total proteins were prepared at the indicated time points

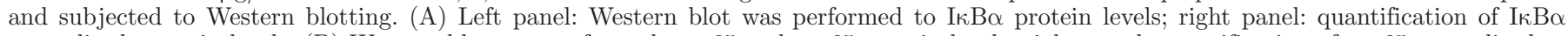
normalized to actin levels. (B) Western blot was performed to p65 and p-p65 protein levels; right panel: quantification of p-p65 normalized to p65 levels. $\bmod =$ cells treated with LPS $(50 \mu \mathrm{g} / \mathrm{mL})$ only; low $=$ caffeic acid $(10 \mu \mathrm{g} / \mathrm{mL})+\mathrm{LPS}(50 \mu \mathrm{g} / \mathrm{mL}) ; \mathrm{mid}=\mathrm{caffeic}$ acid $(25 \mu \mathrm{g} / \mathrm{mL})$ + LPS $(50 \mu \mathrm{g} / \mathrm{mL})$, high $=$ caffeic acid $(50 \mu \mathrm{g} / \mathrm{mL})+$ LPS $(50 \mu \mathrm{g} / \mathrm{mL})$. Data in $(\mathrm{A})$ and $(\mathrm{B})$ are shown as means \pm SEM $(\mathrm{n}=3)$. \#\#\# $P<$ 0.01 vs. control group; ${ }^{* *} P<0.01$ vs. group treated with LPS only; ${ }^{* * *} P<0.001$ vs. group treated with LPS only. One out of 3 independent experiments is shown.

signal-regulated kinase $1 / 2$, or c-Jun $\mathrm{NH}_{2}$-terminal kinase $1 / 2$, leading to activation of NF- $\kappa \mathrm{B}$ in Raw 264.7 macrophages, and caffeic acid or its derivatives can affect these signaling pathways (Cario et al., 2000; Jung et al., 2008). Therefore, other possible pathways and targets related to the antiinflammatory effect of caffeic acid in LPS-caused inflammation injury of bMEC need to be further researched. In addition, a series of in vivo experiments will be performed to test the antiinflammatory effect of caffeic acid in the future. 


\section{CONCLUSIONS}

This study demonstrated the protective effect of caffeic acid on LPS-induced inflammation injury in bMEC. This effect was at least partly achieved by the decreased production of proinflammatory cytokines mediated by the effect of reducing the $\mathrm{I} \kappa \mathrm{B} \alpha$ degradation and p65 phosphorylation in the NF- $\mathrm{B}$ pathway. The antiinflammatory effect of caffeic acid occurred in a dose-dependent manner. Caffeic acid possesses potential antiinflammatory activity and beneficial characteristics for the treatment of bovine mastitis-causing $E$. coli. But other possible pathways and targets related to the antiinflammatory effect of caffeic acid need to be researched in the future.

\section{ACKNOWLEDGMENTS}

This work was supported by grants from National Twelve-Five Technological Supported Plan of China (Beijing, China; No. 2011BAD34B01) and the Project of Construction of Innovative Teams and Teacher Career Development (PXM2013_014207_000067). We are thankful for the help from the members of China Agricultural University-Beijing University of Agriculture teaching and research team (CAU-BUA TCVM, Beijing, China).

\section{REFERENCES}

Boehmer, J. L. 2011. Proteomic analyses of host and pathogen responses during bovine mastitis. J. Mammary Gland Biol. Neoplasia 16:323-338

Botrel, M.-A., M. Haenni, E. Morignat, P. Sulpice, J.-Y. Madec, and D. Calavas. 2010. Distribution and antimicrobial resistance of clinical and subclinical mastitis pathogens in dairy cows in RhôneAlpes, France. Foodborne Pathog. Dis. 7:479-487.

Bougarn, S., P. Cunha, A. Harmache, A. Fromageau, F. B. Gilbert, and P. Rainard. 2010. Muramyl dipeptide synergizes with Staphylococcus aureus lipoteichoic acid to recruit neutrophils in the mammary gland and to stimulate mammary epithelial cells. Clin. Vaccine Immunol. 17:1797-1809.

Bradley, A. J., K. A. Leach, J. E. Breen, L. E. Green, and M. J. Green. 2007. Survey of the incidence and aetiology of mastitis on dairy farms in England and Wales. Vet. Rec. 160:253-257.

Búfalo, M. C., I. Ferreira, G. Costa, V. Francisco, J. Liberal, M. T Cruz, M. C. Lopes, M. T. Batista, and J. M. Sforcin. 2013. Propolis and its constituent caffeic acid suppress LPS-stimulated proinflammatory response by blocking NF- $\kappa \mathrm{B}$ and MAPK activation in macrophages. J. Ethnopharmacol. 149:84-92.

Burvenich, C., V. Van Merris, J. Mehrzad, A. Diez-Fraile, and L. Duchateau. 2003. Severity of E. coli mastitis is mainly determined by cow factors. Vet. Res. 34:521-564.

Calvinho, L. F., R. A. Almeida, and S. P. Oliver. 2001. Influence of bacterial factors on proliferation of bovine mammary epithelial cells. Rev. Argent. Microbiol. 33:28-35.

Calzado, M. A., S. Bacher, and M. L. Schmitz. 2007. NF-kappaB inhibitors for the treatment of inflammatory diseases and cancer. Curr. Med. Chem. 14:367-376.

Cario, E., I. M. Rosenberg, S. L. Brandwein, P. L. Beck, H.-C. Reinecker, and D. K. Podolsky. 2000. Lipopolysaccharide activates distinct signaling pathways in intestinal epithelial cell lines expressing tolllike receptors. J. Immunol. 164:966-972.

Ghosh, S., and M. S. Hayden. 2008. New regulators of NF- $\kappa$ B in inflammation. Nat. Rev. Immunol. 8:837-848.

Günther, J., W. Petzl, H. Zerbe, H.-J. Schuberth, D. Koczan, L. Goetze, and H.-M. Seyfert. 2012. Lipopolysaccharide priming enhances expression of effectors of immune defence while decreasing expression of pro-inflammatory cytokines in mammary epithelia cells from cows. BMC Genomics 13:17.

Hines, D. J., H. B. Choi, R. M. Hines, A. G. Phillips, and B. A. MacVicar. 2013. Prevention of LPS-induced microglia activation, cytokine production and sickness behavior with TLR4 receptor interfering peptides. PLoS ONE 8:e60388.

Hoeben, D., C. Burvenich, E. Trevisi, G. Bertoni, J. Hamann, R. M. Bruckmaier, and J. W. Blum. 2000. Role of endotoxin and TNFalpha in the pathogenesis of experimentally induced coliform mastitis in periparturient cows. J. Dairy Res. 67:503-514.

Hoffmann, A., and D. Baltimore. 2006. Circuitry of nuclear factor $\kappa \mathrm{B}$ signaling. Immunol. Rev. 210:171-186.

Hoffmann, A., A. Levchenko, M. L. Scott, and D. Baltimore. 2002 The I $\kappa-N F-\kappa B$ signaling module: Temporal control and selective gene activation. Science 298:1241-1245.

Ibeagha-Awemu, E. M., J.-W. Lee, A. E. Ibeagha, D. D. Bannerman, M. J. Paape, and X. Zhao. 2008. Bacterial lipopolysaccharide induces increased expression of toll-like receptor (TLR) 4 and downstream TLR signaling molecules in bovine mammary epithelial cells. Vet. Res. 39:11.

Jung, J. E., H. S. Kim, C. S. Lee, D.-H. Park, Y.-N. Kim, M.-J. Lee, J. W. Lee, J.-W. Park, M.-S. Kim, S. K. Ye, and M.-H. Chung. 2007. Caffeic acid and its synthetic derivative CADPE suppress tumor angiogenesis by blocking STAT3-mediated VEGF expression in human renal carcinoma cells. Carcinogenesis 28:1780-1787.

Jung, W.-K., I. Choi, D.-Y. Lee, S. S. Yea, Y. H. Choi, M.-M. Kim, S.G. Park, S.-K. Seo, S.-W. Lee, C.-M. Lee, Y.-M. Park, and I.-W. Choi. 2008. Caffeic acid phenethyl ester protects mice from lethal endotoxin shock and inhibits lipopolysaccharide-induced cyclooxygenase- 2 and inducible nitric oxide synthase expression in RAW 264.7 macrophages via the p38/ERK and NF- $\kappa$ B pathways. Int. J. Biochem. Cell Biol. 40:2572-2582.

Karin, M., and Y. Ben-Neriah. 2000. Phosphorylation meets ubiquitination: The control of NF- $\kappa \mathrm{B}$ activity. Annu. Rev. Immunol 18:621-663.

Kerro Dego, O., S. P. Oliver, and R. A. Almeida. 2012. Host-pathogen gene expression profiles during infection of primary bovine mammary epithelial cells with Escherichia coli strains associated with acute or persistent bovine mastitis. Vet. Microbiol. 155:291-297.

Klement, J. F., N. R. Rice, B. D. Car, S. J. Abbondanzo, G. D. Powers, P. H. Bhatt, C.-H. Chen, C. A. Rosen, and C. L. Stewart. 1996 $\mathrm{I} \kappa \mathrm{B} \alpha$ deficiency results in a sustained NF- $\kappa \mathrm{B}$ response and severe widespread dermatitis in mice. Mol. Cell. Biol. 16:2341-2349.

Lahouassa, H., E. Moussay, P. Rainard, and C. Riollet. 2007. Differential cytokine and chemokine responses of bovine mammary epithelial cells to Staphylococcus aureus and Escherichia coli. Cytokine $38: 12-21$.

Lee, Y., D. Shin, J.-H. Kim, S. Hong, D. Choi, Y.-J. Kim, M.-K. Kwak, and Y. Jung. 2010. Caffeic acid phenethyl ester-mediated Nrf2 activation and $\mathrm{I} \kappa \mathrm{B}$ kinase inhibition are involved in $\mathrm{NF} \kappa \mathrm{B}$

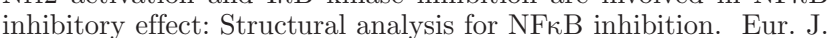
Pharmacol. 643:21-28.

Li, Q., and I. M. Verma. 2002. NF- $\kappa$ B regulation in the immune system. Nat. Rev. Immunol. 2:725-734.

Menzies, F. D., D. G. Bryson, T. McCallion, and D. I. Matthews. 1995. A study of mortality among suckler and dairy cows in Northern Ireland in 1992. Vet. Rec. 137:531-536.

Miyake, K. 2004. Endotoxin recognition molecules, toll-like receptor 4-MD-2. Semin. Immunol. 16:11-16.

Morimoto, K., N. Kanda, S. Shinde, and N. Isobe. 2012. Effect of enterotoxigenic Escherichia coli vaccine on innate immune function of bovine mammary gland infused with lipopolysaccharide. J. Dairy Sci. 95:5067-5074. 
Petzl, W., H. Zerbe, J. Günther, W. Yang, H. M. Seyfert, G. Nürnberg, and H. J. Schuberth. 2008. Escherichia coli, but not Staphylococcus aureus triggers an early increased expression of factors contributing to the innate immune defense in the udder of the cow. Vet. Res. 39:18

Porcherie, A., P. Cunha, A. Trotereau, P. Roussel, F. B. Gilbert, P. Rainard, and P. Germon. 2012. Repertoire of Escherichia coli agonists sensed by innate immunity receptors of the bovine udder and mammary epithelial cells. Vet. Res. 43:14.

Puangpraphant, S., M. A. Berhow, K. Vermillion, G. Potts, and D. M. E. Gonzalez. 2011. Dicaffeoylquinic acids in Yerba mate (Ilex paraguariensis St. Hilaire) inhibit NF-kappaB nucleus translocation in macrophages and induce apoptosis by activating caspases- 8 and -3 in human colon cancer cells. Mol. Nutr. Food Res. 55:1509-1522.

Quesnell, R. R., S. Klaessig, J. L. Watts, and Y. H. Schukken. 2012. Bovine intramammary Escherichia coli challenge infections in late gestation demonstrate a dominant antiinflammatory immunological response. J. Dairy Sci. 95:117-126.

Risco, A., C. del Fresno, A. Mambol, D. Alsina-Beauchamp, K. F. MacKenzie, H.-T. Yang, D. F. Barber, C. Morcelle, J. S. C. Ar-

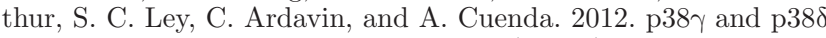
kinases regulate the toll-like receptor 4 (TLR4)-induced cytokine production by controlling ERK1/2 protein kinase pathway activation. Proc. Natl. Acad. Sci. USA 109:11200-11205.

Scheibel, M., B. Klein, H. Merkle, M. Schulz, R. Fritsch, F. R. Greten, M. C. Arkan, G. Schneider, and R. M. Schmid. 2010. I $\kappa B \beta$ is an essential co-activator for LPS-induced IL-1 $\beta$ transcription in vivo. J. Exp. Med. 207:2621-2630.

Schmitz, S., M. W. Pfaffl, H. H. D. Meyer, and R. M. Bruckmaier. 2004. Short-term changes of mRNA expression of various inflammatory factors and milk proteins in mammary tissue during LPSinduced mastitis. Domest. Anim. Endocrinol. 26:111-126.

Seegers, H., C. Fourichon, and F. Beaudeau. 2003. Production effects related to mastitis and mastitis economics in dairy cattle herds. Vet. Res. 34:475-491.

Shimazu, R., S. Akashi, H. Ogata, Y. Nagai, K. Fukudome, K. Miyake, and M. Kimoto. 1999. MD-2, a molecule that confers lipopolysaccharide responsiveness on toll-like receptor 4. J. Exp. Med. 189:1777-1782.

Shin, K.-M., I.-T. Kim, Y.-M. Park, J. Ha, J.-W. Choi, H.-J. Park, Y. S. Lee, and K.-T. Lee. 2004. Anti-inflammatory effect of caffeic acid methyl ester and its mode of action through the inhibition of prostaglandin E2, nitric oxide and tumor necrosis factor- $\alpha$ production. Biochem. Pharmacol. 68:2327-2336.
Shuster, D. E., M. J. Kehrli Jr., P. Rainard, and M. Paape. 1997. Complement fragment C5a and inflammatory cytokines in neutrophil recruitment during intramammary infection with Escherichia coli. Infect. Immun. 65:3286-3292.

Strandberg, Y., C. Gray, T. Vuocolo, L. Donaldson, M. Broadway, and R. Tellam. 2005. Lipopolysaccharide and lipoteichoic acid induce different innate immune responses in bovine mammary epithelial cells. Cytokine 31:72-86.

Sun, S. C., P. A. Ganchi, D. W. Ballard, and W. C. Greene. 1993. NF$\kappa \mathrm{B}$ controls expression of inhibitor I $\mathrm{B} \alpha$ : Evidence for an inducible autoregulatory pathway. Science 259:1912-1915.

Tran, K., M. Merika, and D. Thanos. 1997. Distinct functional properties of $\mathrm{I} \kappa \mathrm{B} \alpha$ and I $\mathrm{KB} \beta$. Mol. Cell. Biol. 17:5386-5399.

Wang, L.-C., K.-H. Chu, Y.-C. Liang, Y.-L. Lin, and B.-L. Chiang. 2010. Caffeic acid phenethyl ester inhibits nuclear factor- $\kappa \mathrm{B}$ and protein kinase B signalling pathways and induces caspase-3 expression in primary human $\mathrm{CD} 4^{+} \mathrm{T}$ cells. Clin. Exp. Immunol. 160:223-232.

Wellnitz, O., A. Baumert, M. Saudenowa, and R. M. Bruckmaier. 2010. Immune response of bovine milk somatic cells to endotoxin in healthy quarters with normal and very low cell counts. J. Dairy Res. 77:452-459.

Wellnitz, O., and R. M. Bruckmaier. 2012. The innate immune response of the bovine mammary gland to bacterial infection. Vet. J. $192: 148-152$

Wellnitz, O., and D. E. Kerr. 2004. Cryopreserved bovine mammary cells to model epithelial response to infection. Vet. Immunol. Immunopathol. 101:191-202.

Yamamoto, M., S. Yamazaki, S. Uematsu, S. Sato, H. Hemmi, K. Hoshino, T. Kaisho, H. Kuwata, O. Takeuchi, K. Takeshige, T. Saitoh, S. Yamaoka, N. Yamamoto, S. Yamamoto, T. Muta, K. Takeda, and S. Akira. 2004. Regulation of toll/IL-1-receptormediated gene expression by the inducible nuclear protein $\mathrm{I} \kappa \mathrm{B} \zeta$. Nature 430:218-222.

Yu, J., P. Yin, F. Liu, G. Cheng, K. Guo, A. Lu, X. Zhu, W. Luan, and J. Xu. 2010a. Effect of heat stress on the porcine small intestine: A morphological and gene expression study. Comp. Biochem. Physiol. A Mol. Integr. Physiol. 156:119-128.

Yu, J., P. Yin, J. Yin, F. Liu, X. Zhu, G. Cheng, K. Guo, Y. Yin, and J. Xu. 2010b. Involvement of ERK1/2 signalling and growth-related molecules' expression in response to heat stress-induced damage in rat jejunum and IEC-6 cells. Int. J. Hyperthermia 26:538-555. 